\title{
WHEN UNIONS "MATTERED": ASSESSING THE IMPACT OF STRIKES ON FINANCIAL MARKETS: 1925-1937
}

\author{
John DiNardo \\ Kevin F. Hallock \\ Working Paper 7794 \\ http://www.nber.org/papers/w7794 \\ NATIONAL BUREAU OF ECONOMIC RESEARCH \\ 1050 Massachusetts Avenue \\ Cambridge, MA 02138 \\ July 2000
}

We thank Orley Ashenfelter, Sherrilyn Billger, Dale Belman, Richard Block, Kevin Denny, Ben Gordon, Wally Hendricks, Margaret Chaplan, Mark Moore, Larry Neal, Martin Wagner and participants at the Ninth Bargaining Group Conference at Michigan State University for discussions and suggestions and the editor and referees for helpful comments. Matt Artz and Xiang Yi provided excellent research assistance. We are grateful to the Institute of Labor and Industrial Relations at the University of Illinois for financial support. We are also extremely grateful to Margaret Chaplan and Katie Dorsey from The Industrial Relations Library at the University of Illinois for their help in identifying and locating data. The views expressed here are the authors' and do not necessarily reflect those of the National Bureau of Economic Research.

(C) 2000 by John DiNardo and Kevin F. Hallock. All rights reserved. Short sections of text, not to exceed two paragraphs, may be quoted without explicit permission provided that full credit, including $\mathbb{C}$ notice, is given to the source. 
When Unions "Mattered": Assessing the Impact of Strikes on Financial Markets: 1925-1937

John DiNardo and Kevin F. Hallock

NBER Working Paper No. 7794

July 2000

JEL No. J5, G3

$\underline{\text { ABSTRACT }}$

Combining information from labor historians and using techniques from finance we analyze the strikes "that labor historians have agreed are pivotal in American history" during the period 1925-1937. Using information we collected on strike dates and historical financial market stock price data we assess the financial market's view of these conflicts. We study the effects of major strikes between the world wars on detailed industry stock prices. We find that strikes have large, negative effects on industry stock value. We also find that longer strikes, violent strikes, strikes where unions "win," industry-wide strikes, strikes that lead to union recognition, and strikes that lead to large wage increases lead to larger negative share price reactions than other strikes. Also, our analysis shows that most of the "news" in a strike seems to be incorporated very early on in the strike. Our analysis strongly suggests that although the financial markets generally expected unions to "lose," they viewed union victories as quite important determinants of the share of firm profits going to stockholders.

John DiNardo

Department of Economics

University of California - Irvine

Irvine, CA 92797

and NBER

jdinardo@uci.edu
Kevin F. Hallock

Department of Economics

and Institute of Labor and Industrial Relations University of Illinois at Urbana-Champaign

504 East Armory Avenue

Champaign, IL 61820

hallock@uiuc.edu 


\section{Background}

Unions have well-documented effects on their members and on the firms that employ these workers. (See Freeman and Medoff (1984) for one review). One question that has received less attention is the extent to which unions have effects on non-union workers and firms which do not employ union workers. A limited and narrowly-focused literature in labor economics on "union threat effects" (effects of unionization on the wages of the nonunionized), for example, has been rather inconclusive. (See Freeman and Medoff (1981), Neumark and Wachter (1995), DiNardo, Hallock and Pischke (1997) and Leicht (1989) for example). Moreover, there appears to be little consensus on whether the combination of direct effects (the effect of unionization on the unionized) and indirect effects (the effect on the nonunionized) is even positive. (See Bound and Johnson (1995) for a clear recent statement of the view).

A primary weakness of the most recent empirical literature, however, is that the magnitude and type of variation in unionization in the recent past is arguably insufficient (even if appropriately exogenous) to estimate "indirect" effects. For example, the most striking aspect of recent research using information from union certifications over the last twenty years is the small level of this type of activity. (Bronars and Deere 1993, DiNardo et al. 1997).

Our study begins with the premise that the extent of union effects is potentially easier to detect when changes in unionization are large and important. Toward that end we focus on the period between the two world wars, an important time for the U.S. labor movement. After witnessing a prodigious and rapid increase in membership at the end of the nineteenth century, American unionism experienced a decline of almost equal magnitude in the period leading up to the first World War. Indeed the ferocity of business and government hostility to the attempt to organize American workers left little doubt about the importance of the struggle. As we will argue below, this period and the period leading up to World War II 
provide a unique time to investigate the impact of strikes on firms.

We focus on the economic consequences of strikes during the interwar period as reflected in the behavior of the stock market. Our point of departure is that the strikes we identify during this period (especially as compared to the present) were primarily an attempt by workers to change the "terms of trade" between workers and their employers. We then evaluate, using standard event-study methods, the effect of various important strike characteristics on broad industry-level measures of equity prices. While several studies (e.g. Becker and Olson (1986) Neumann (1990) Kramer and Vasconcellos (1996) and Persons (1995)) have investigated the link between strikes and stock prices, these studies focus on a much more recent period where data are publicly available, and the importance of the strikes for the structure of industrial relations is arguably much smaller than in the time period we consider.

Given our focus on strikes, our paper is directly related to two literatures. In one, (see Neumann and Reder (1984)) the effect of strikes on industry wide output is measured using industry-wide measures such as inventories, shipments, etc. In another, the lost value associated with strikes is measured using data on market valuation (see Ruback and Zimmerman (1984) for example). This literature is closely related to the "event study" literature in finance and has focused exclusively on using stock market returns from individual firms. At its most basic level, our approach is a "combination" of both approaches. Like the firm level studies, we use information from the capital markets; unlike that literature, and in common with the literature on the "industry-wide" effect of strikes, we focus on broadly defined industrial aggregates.

Our paper then is essentially an examination of the impact of strikes on industry stock prices at a time when unions were rapidly evolving. The outline of the paper is as follows. In Section 2, we develop a simple analytical framework for examining the relationship between strikes and stock prices. Section 3 briefly describes the historical context and in Section 4 we describe our data. Section 5 is a brief description of the well-known event 
study method. Section 6 describes our empirical results, and Section 7 compares our findings with those from studies using more recent data. Section 8 concludes.

\section{Analytical Framework}

At first glance, it might be surprising to find any effect of strike activity on industry wide measures of output. The first puzzle involves why strikes should have any effect on the returns of individual firms. In the context of an infinitely lived firm, and when strikes have no effect on the terms of trade, the change in the value of discounted earnings streams would be quite small. Given the considerable evidence that the measured change in market values of firms resulting from strikes is not negligible (e.g. Becker and Olson (1986), Neumann (1990), and Ruback and Zimmerman (1984)) we follow the earlier literature and presume that it is meaningful to investigate the presence of such an effect.

Once we depart from the single firm and consider the entire industry, it is necessary for us to consider the effect of union bargains on non-unionized firms or those not immediately party to the contract negotiations. ${ }^{1}$ One's a priori view of the sign/magnitude of these indirect effects depends on the mechanism by which unions (in this historical context) raise wages.

The simplest way to proceed is to adopt the view that unions act as a cartelling mechanism. In an otherwise perfectly competitive industry, the effect of unionization could be quite dramatic. Indeed, in this view unionism is best characterized as a potentially fatal infection as in Kremer (1999). ${ }^{2}$ The firm, uniquely targeted to pay above market wages is replaced by other non-unionized firms. The evidence for this view is minimal. While unions negatively impact market valuations of a firm, prima facie, the fact that unionized and non-unionized firms coexist, suggests that it is not always the case that all the assets

\footnotetext{
${ }^{1}$ See Lazear (1983) for some of the subtleties involved.

${ }^{2}$ It should be noted however, that in Kremer's (1999) more nuanced and articulated framework, firm death is only one of several possible outcomes.
} 
of the firm are reassigned to other (more productive and profitable) non-union firms even in the very long run. Under this view, it is far from clear that the effect of a strike should have significant effects on broad industry wide aggregates. If other non-unionized firms fill in the breach, the impact of the strike will still be rather small.

Efficient contract or "Nash bargaining" models provide yet another basis for expectations regarding the effect of strikes on the firm (Brown and Ashenfelter 1986, MaCurdy and Pencavel 1986). In these models, firms have economic profits which the union seeks to extract.

If one views a "successful" strike as a one time "permanent" change in the share of the surplus going to workers, the effect of the strike on the value of the firm will be proportional to the change in profits going to the firm. The effect on industrial activity at large will be small to the extent that the strike's effects are limited exclusively to the struck firm and/or the firm's share of output is small.

To prepare the way for our empirical analysis, consider the extreme case of when wage bargains reached by unions accrue to all workers in an industry. ${ }^{3}$ Again for simplicity, we assume a constant real rate of interest $r$. Before the strike, the industry faces a probability $\pi$ of a one-time permanent change in the value of firm due to the fact that the union calls a strike and wins. ${ }^{4}$ If we denote earnings in a given time period by $D$, and the percentage change in the share going to the firm by $-\delta$ the value of the firm prior to the strike decision is:

$$
E\left[V_{0}\right]=\pi \int_{0}^{\infty} e^{-r t} D(1-\delta) d t+(1-\pi) \int_{0}^{\infty} e^{-r t} D d t
$$

If the union strikes and wins, the value of the firm is merely:

\footnotetext{
${ }^{3}$ The presentation could be made more realistic by considering a finite time horizon or the possibility of future union wins or losses, but this would merely complicate the expressions without adding additional insight.

${ }^{4} 1-\pi$, then, is the probability that the union doesn't call a strike or calls one and loses.
} 


$$
V_{\text {union strike and win }}=\int_{0}^{\infty} e^{-r t} D(1-\delta) d t
$$

The percentage change in the value of the firm (or log difference) when the union wins is then given by:

$$
\begin{aligned}
& \text { Percent change in the value of the firm }= \\
& \begin{aligned}
\log \left(E\left[V_{0}\right]\right)-\log \left(V_{\text {union strikes and wins }}\right) & =\log \left(\frac{1-\delta \pi}{1-\delta}\right) \\
& \approx(1-\pi) \delta
\end{aligned}
\end{aligned}
$$

This expression has a simple interpretation. The percentage change in the value of the firm when the union strikes and wins an important fight is equal to the product of the probability that the union loses or does not strike at all $(1-\pi)$ and the fraction of earnings that flow away from shareholders towards workers $(\delta)$. If firms completely anticipate a union strike and victory $(\pi=1)$ and this information were already incorporated into the value of the firm, a strike would have no effect on excess returns.

The analysis is completely symmetrical for the case where the union does not strike or strikes and loses. In this case, the magnitude of the measured effect of union losses on stock prices will be largest when the probability firms attach to a union loss are small. The measured effect of a union loss on stock returns will be small whenever a union defeat is likely.

The interpretations are summarized in the table below. We interpret changes in excess returns at the industry level as evidence that unions have industry-wide effects. If union threat effects are unimportant, or unions only affect the "struck" employer, we expect changes in industry excess returns to be zero. On the other hand, if union threat effects are important, we expect non-zero changes in excess returns. Furthermore, if the probability 
of a union victory is small, we expect negative changes in excess returns when the union wins, and much smaller positive values for union defeats.

\begin{tabular}{|c|c|c|c|}
\hline \multirow[b]{2}{*}{ Event } & \multirow[b]{2}{*}{ Prior Belief } & \multicolumn{2}{|c|}{ Effect of Strike on Stock Returns When: } \\
\hline & & $\begin{array}{l}\text { Unions have small } \\
\text { indirect impacts } \\
\text { on industry returns }\end{array}$ & $\begin{array}{l}\text { Unions have large } \\
\text { indirect impacts } \\
\text { on industry returns }\end{array}$ \\
\hline \multirow[t]{2}{*}{ Union loses } & Probability of loss is high & 0 & positive, small \\
\hline & Probability of loss is low & 0 & positive, large \\
\hline \multirow[t]{2}{*}{ Union wins } & Probability of win is high & 0 & negative, small \\
\hline & Probability of win is low & 0 & negative, large \\
\hline
\end{tabular}

\section{Historical Context}

As mentioned in the introduction, the interwar period is particularly interesting / unique for our analysis. The role of the state during most of the sample period was either absent or hostile to unionism. Moreover, it is clear that most participants firmly believed that the outcome of the battle between capital and labor was of great significance and the immediate stakes were enormous. For example, at the beginning of our sample period the Industrial Workers of the World began as "the last important national organization to challenge the philosophy of business unionism ... [ but by the end of World War I had become] a tiny organization whose status as a labor union was questionable." (Rees 1977) Moreover, it is quite clear (particularly before 1934) that "unions existed in a predominately noninstitutionalized setting. Union recognition, collective bargaining and labor-management contractual agreements were not yet legal, and in fact much of the conflict between labor and capital was over the right to organize."(Rubin 1986) At the same time, the government's attempts to avert strikes that might damage wartime production and other concerns led to the passage of the Clayton Act. The Clayton Act abolished the legal framework which had most limited union organizing - the principle that unions violated the Sherman 
Anti-trust Act by acting as a "restraint on trade." 5 As a consequence, the interwar period was arguably the crucible that set the terms of trade under which unions would be tolerated by business and the government after World War II and serves as an ideal context to study the impact of strikes on stock prices.

In addition, unlike the period after World War II, the role of the state in providing income support (sometimes viewed as an "alternative" to unionism) was rather small. Moreover, the institutional features that were to mark postwar industrial relations were forged in part during this critical period. "Pattern bargaining" and the creation of industrial relations schools were formed in light of the perception of the "relative permanence" of collective bargaining. By way of contrast, during the interwar period the view of collective bargaining as "normal" or "inevitable" was not widespread. This belief was reflected in the nature of the strikes which generally occurred over debates on fundamental aspects of workplace relations.

\section{Data}

The two main data sources for this paper are the information on the specific strikes and industry financial data. The first set of data come from a history of significant strikes from the relevant time period (Filippelli 1990). The stock price data are from a Yale University report (Cowles and Associates 1938). In each case, we had to go through the sources by hand (or use scanning technology along with Optical Character Recognition (OCR) software to collect the data).

We investigated a broad set of possibilities for collecting data on strikes from this particularly important period in labor history including, for example, Peterson (1938). However, only one that we were able to locate offered us the exact relevant dates associated

\footnotetext{
${ }^{5}$ In practice, of course, the Clayton Act was not a panacea for American trade unionism. Indeed, in the first twenty four years after its passage more cases of antitrust violations were brought against labor than in the twenty four preceding years. See (Fisher 1940).
} 
with the strike which are crucial to the event study method we employ and describe below. This book, Labor Conflict in the United States: An Encyclopedia, gives detailed accounts of various important strikes during our time period written by a host of authors and compiled by Filippelli (1990). Obviously, we only focus attention on a certain select set of strikes. Filippelli (1990) examines 254 total strikes over a very long time period. Over the time period we consider, in part due to limitations of our financial market data, we examine 36 strikes. In describing the strikes selected in Filippelli's (1990) book, he states that “... it is hoped that all of the conflicts that labor historians have agreed are pivotal in American history are included. These are the strikes that appear in all standard labor histories." (page xii.)

Importantly, this same source also provides us with a wealth of other valuable information about the strike that allows us to create another set of variables including the duration of the strike, the industry involved in the strike, whether the union was recognized by the struck firm as a result of the strike, whether the union was new or established ${ }^{6}$, the number of strikers involved, whether there was violence during the strike, whether wages were increased, decreased or stayed the same after the strike, and who was the eventual "winner" of the strike (union or management).

Simple statistics for each of the strikes are contained in Table 1. Obviously some of the data in this table is based on purely "objective" criteria, such as the number of strikers, or the date of the start of the strike and is therefore easily culled from the narratives of the strikes. Other data, such as whether the union or firm "won" are more subjective. We discuss these subjective measures below.

The first strike in our sample started in January of 1925 and the last one started in

\footnotetext{
${ }^{6}$ We define an "established" or "old" union by first identifying the name of the union from accounts in Filippelli (1990) and a variety of other sources (Gifford 1999, Reynolds and Killingsworth 1944, Fink 1977) to identify the date the union was established: Unions older than three years were defined as established. Our results are robust to different definitions of "established".
} 
May of $1937^{7}$. The strikes occurred in 17 different industries. The average strike duration was 5.5 months. Violence was mentioned in the narratives in just over half of the strikes. Wages decreased in only a handful of cases, stayed the same in about half, and increased in just over a third of strikes. Following Card and Olson (1995), we also attempted to identify the "winner" of the strike. ${ }^{8}$ To situate our sample in the broader sample of all strikes that occurred during this period, we present some information from Griffin (1939) who includes a much larger set of strikes in his analysis of strikes from 1880-1937. Figure 1 (which was generated using data from the Griffin study) reveals that for the period 1925-1937 (the period we analyze), that the median annual percentage was 35 percent for "success" (from the perspective of the unions), 33.4 percent for "failed", and 30.7 percent for compromise. Given the consistency with our estimates, we conclude that our sample of strikes, apart from their greater "importance", are not radically different from the broader sample of strikes.

Our stock price data come from Cowles (1938) Common-Stock Indexes: 1871-193\%. This book contains several series for common stocks by industry by month over a relatively long time period. One distinguishing characteristic of the book is that its description of the data and industries are the product of a tremendous amount of effort and meticulous attention to detail. The indexes covered include: dividend payments, price-earnings ratios, earnings, stock prices, and stock prices including cash dividends. For each industry, we scanned in the stock prices including cash dividends for each month from 1916-1937 (although we only use the data from 1925 - 1937 here). Since there is no information for a four month period during World War I, this leaves us with 380 months of data for

\footnotetext{
${ }^{7}$ There are later strikes contained in the Filippelli (1990) volume but our stock price data (described below) end at the end of 1937.

${ }^{8}$ We identified the union to be the winner in 53 percent of the strikes. Obviously it is not always easy to identify the "winner" of a strike. We determined the winner based our subjective evaluation of the Filippelli narratives. In ten percent of the cases, see Table 1, the winner of the strike is not clear. Our results are insensitive to our treatment of the ambiguous cases. Below, we further investigate the strikes which led to union recognition, often one of the key goals of the strikers.
} 
each industry. Since we collected information on 69 industries this gives us 36,220 industry/months of data. ${ }^{9}$ It is also worth noting that we do not have complete information on security prices for all industries for the entire time period. One example is absence of stock prices for automobiles and trucks, which as of the late 19th century, had not yet been invented. Figure 2 displays the average stock price over time using these data. The dramatic increase up to the great crash of 1929 is clear from the figure, as is the subsequent increase.

\section{The Event Study Method}

A goal of our work is to assess the impact of strikes on industry stock prices during the interwar period. The most straightforward method would be as follows: merely examine industry stock returns before and after the strike and then attribute the entire stock price change to the effects of the strike. This is only appropriate however, if general economy wide conditions are unchanging during the strike period. If not, then we need to generate an assessment of the movement of stock prices that would have occurred in the absence of the strike.

The event study method has been widely used in industrial relations research, including for example, Becker and Olson (1986), and Abowd, Milkovich and Hannon (1990). The technical aspects of the method we employ are carefully described in Brown and Warner (1985), Campbell, Lo and MacKinlay (1997), Fama, Fisher, Jensen and Roll (1969), and MacKinlay (1997). We will therefore describe the basic ideas only briefly. We begin by concentrating on the effect of a strike around the start of the strike.

Cumulative average excess returns are calculated using the very simple model outlined below. Let $\mathrm{t}$ index time in trading months, let s indicate the "event month" (the month

\footnotetext{
${ }^{9}$ The scanning technology along with Optical Character Recognition (OCR) software worked remarkably well. We hand-checked each observation and found that only about 4 percent were in error.
} 
of the start of the strike), and let $i$ indicate industries. First the industry monthly stock return, $R_{i t}$, is regressed on $R_{m t}$, the average market return for month $t$, which we also collected from the Cowles (1938) data. This regression,

$$
R_{i t}=\alpha_{i}+\beta_{i} R_{m t}+\eta_{i t}
$$

is estimated for a period ${ }^{10}$ from month $s-24$ to month $s-12$. We estimate this regression for a period preceding the strike so as to avoid potential contamination of our counterfactual by expectations of a strike. This allows us to assess the behavior of the industry prices relative to the market in the absence of the strike. The next step is to compute abnormal returns (or excess returns) for each month around the event date in the following way:

$$
E R_{i t}=R_{i t}-\left(\hat{\alpha}_{i}+\hat{\beta}_{i} R_{m t}\right)
$$

where $\hat{\alpha}_{i}$ and $\hat{\beta}_{i}$ are the estimated regression coefficients from equation (5). $E R_{i t}$ is then the excess return for each industry $i$ for each month $t$. It is the difference between the actual return $R_{i t}$ and the predicted return $\left(\hat{\alpha}_{i}+\hat{\beta}_{i} R_{m t}\right)$ based on the estimated parameters from equation (5). In the absence of strikes $E R_{i t}$ should clearly equal zero on average.

The excess returns calculated for each month around the start of a strike are used to calculate the average excess returns for each strike. These are easily computed by averaging the monthly excess returns for each strike. We also compute the "cumulative" excess returns, which are computed by adding monthly excess returns for various intervals (called event "windows") around the date of the strike. Cumulative average excess returns are, therefore, clearly just the average of these cumulative excess returns across all strikes.

The tests for statistical significance and the precise statistic used are discussed in Campbell et al. (1997). These tests proceed by observing that average excess returns and cumulative average excess returns, in the absence of "news" which permanently alters the value

\footnotetext{
${ }^{10}$ We tried other prediction periods with no meaningful effect on the results.
} 
of the firm, should be zero. The extent that these returns are different from zero is evidence that supports the hypothesis that the events we have identified provided important news.

Another issue is the definition and timing of the event. In the typical event study, where excess returns over a period of a few days are being evaluated, defining the timing of the event is critically important and often very difficult. Researchers must be able to carefully identify when participants in capital markets first became aware of news. We are not as concerned with this issue, since our periods are measured in months. Other implications of the timing are discussed below.

\section{Empirical Results}

In many traditional financial event studies, it is transparent how one dates an "event"; while clear in most cases, it is not quite so clear in our example. In principle, the appropriate date is the date at which most of the "information" in the strike is incorporated. If the financial markets are forward-looking, and most of the information is revealed at the beginning of the strike then the date of the strike announcement is most relevant. Table 2 presents our estimates of cumulative average excess industry stock returns for various windows relative to the strike announcement date.

Each column of the table reports results based on a different event window: month 0 (this is simply the excess return during the strike start month averaged over all strikes), month 0 to month +1 (this is the sum of the excess returns over the two month period from the month of the strike announcement to the month after the announcement averaged over all strikes), month -1 to month 0 , month -1 to month +1 , month -2 to month +2 , and month -3 to month +3 . In principle, results from all windows should be roughly the same. If the frequency of our stock price information were daily, we could date strike announcements perfectly, and if "news" is transmitted and markets react quickly, we would expect that the shortest window to be the most appropriate window. However, given the 
frequency of the stock data and our a priori expectations on the speed of transmission of economic news from strikes during the interwar period, our preferred results are those that use the windows from $t=-1$ to 1 month. For completeness, we also report results for other wider windows.

The first row of the table summarizes the information for all strikes. The second pair of rows in the table compares union wins to union losses. Subsequent sets of rows report results contrasting "violent" strikes, whether wages went up, down, or remained the same, many (more than the median of 3700) strikers or few strikers, short (less than the median of 2 months) strikes to longer strikes, whether or the strike resulted in recognition of the union by the firm, whether the strike was industry wide, and whether the strike was by an established union (defined above).

The evidence from the table is generally consistent with the view that the financial markets viewed these strikes as important. In general, the results are economically significant and statistically different from zero at conventional levels of significance. For example, the point estimates in the row labeled "union win" indicate losses to the firm of about 7 percent for our preferred specification (month -1 to month +1 ) and are statistically different from zero. In contrast, union losses led to generally quite small stock price changes (-0.1 percent) and not distinguishable from zero at conventional levels of significance.

More striking perhaps, is that when wages fell in response to the strike, the estimated positive impact on the value of the industry was roughly 9 percent using our preferred window width, and statistically different from zero. In contrast, when wages remained the same or increased (a tiny fraction of our total observations) our point estimates indicate that the value of the industry fell between 3 and 5 percent, although our estimates for the cases of "wages up" are imprecise.

It is also interesting to note that strikes leading to the recognition of the union by the firm appeared to have had a much larger negative share price reaction than strikes which did not lead to the recognition of a union. (Compare for example, -0.065 to -0.016 , in 
the month -1 to month +1 window in Table 2). Also, as expected, strikes that involved an entire industry had a much larger negative effect (albeit imprecise) on industry stock prices than strikes involving a single firm (or a small number of firms).

Strikes that involved new versus established unions are the subject of the last two rows of Table 2. It appears that, on average, strikes by established unions lead to larger negative industry share price reactions. Although these estimates are not precise they are consistent with the view that more established unions have more power against management than new unions.

Another interesting pattern in our results is that "bad news" (from the firms' perspective) led to revisions much larger in magnitude than "good news." In terms of the simple model we sketched in the Section 2, this is consistent with a low value for $\pi$, the probability that the workers strike and win. Long strikes led to estimated losses of about 4 percent, whereas short strikes led to very small losses (roughly 1 percent).

The only apparently anomalous results are those for the number of strikers: our point estimates for the effect on stock prices are larger in magnitude for small strikes (-5.6 percent) than for large strikes (-0.8 percent.) This is less anomalous than meets the eye, however, and is explicable by our mechanism for choosing strikes. If size is only one aspect of "importance," then strikes with fewer strikers that made it to the list had to be more important in other dimensions. The results for other window widths are generally insignificantly different from the results for our preferred window widths, and are generally less precise.

Table 3 repeats the analysis, except windows are calculated around the end of the strike. In general, the results are uniformly less precise ${ }^{11}$ and in generally insignificantly different from zero at conventional levels of significance. This is consistent with the view that most of the "news" in strikes occurs at the beginning of the strike, and with other research. The

\footnotetext{
${ }^{11}$ One possible reason for this is that the end of the strike may be difficult identify correctly, especially in those case where the management is defined as the winner.
} 
principal exception is the subsample for which wages fell in response to the strike. In this case, our point estimates of the increase in the value of the firm are on the order of 13 percent.

In Table 4, we combine both windows - around the start of the strike and around the end of the strike. This is appropriate if both the strike announcement and its conclusion contain significant economic news. Perhaps surprisingly, our estimates become somewhat more precise and the magnitude of the effects become much larger. For our preferred window widths, union wins lead to roughly a 3 percent decrease in the value of the firm. For wage changes, our point estimates are quite (almost implausibly) large. Strikes that resulted in lower wages lead to increases of 22 percent in the value of the firm, and strikes with no wage increases led to losses on the order of 7 percent. Likewise, short strikes lead to an increase of roughly 7 percent and our longer strikes led to losses of about 8 percent. In addition, with our preferred window width (month -1 to month +1 ) recognition strikes appear to have led to losses on the order of 10 percent (non-recognition strikes led to small gains), industry wide strikes resulted in losses on the order of 18 percent and strikes by established unions had much larger negative share price reactions than strikes involving new unions.

\section{Comparison With Other Work}

We focus on the relationship between strikes and industry stock prices during the period between the world wars - specifically because this was a time that labor historians and informed observers agree is quite important. Nevertheless, it is interesting to compare our results to those of a host of studies using data from a much more recent time period. Several are noteworthy. For example, in a comprehensive study of the impact of strikes 
on individual firm stock prices from 1962-1982 ${ }^{12}$, Becker and Olson (1986) find that the average large strike represented a 4.1 percent decline in stock prices. Persons (1995) finds that the share price reaction to struck automobile producers and steel suppliers was around 1.6 percent on the days around the strike. Neumann (1990) finds a share price reaction of about 0.5 percent on the day of an announced strike for a sample of firms struck in the late 1960s and mid 1970s. ${ }^{13}$ Nelson, Amoako-Adu and Smith (1994) study 124 Canadian strikes between January 1983 and July 1989 and find a loss in stock price of about 1 percent for the 5 day window around the strike. ${ }^{14}$

Although each of these studies uses a different time period, sample of strikes and event window, they all suggest a negative share price reaction of between 1 and 4 percent around the start of the strike. As we discuss above, our baseline reaction to stock prices (in row 1 of Table 2) is a loss of 3 percent of stock price for the three-month event-window (our preferred specification). Despite this similarity, we should again point out some important differences between our study and the aforementioned studies.

First, our study concentrates on monthly returns; the others concentrate on daily returns. We argue that the decision to study monthly returns is more reasonable for our time period. This assumption would most obviously be problematic for more recent time periods; no doubt, markets react more quickly today than in the past. ${ }^{15}$ Second, our focus is on industries and previous research has focused on share price reactions in individual firms. Finally, we use data from a period where labor historians believe strikes were "pivotal in American History." In any event, our results suggest a relatively large share price

\footnotetext{
${ }^{12}$ The Center for Research in Security Prices (CRSP) at the University of Chicago only published daily stock prices after 1962. All of the previous studies concentrated after this date.

${ }^{13}$ Neumann (1990) goes on to discuss that the stock market seems to predict the occurrence of strikes quite well during this period.

${ }^{14}$ Also see Kramer and Vasconcellos (1996), Davidson, Worrell and Garrison (1988), and Ruback and Zimmerman (1984) for related studies.

${ }^{15}$ Farber and Hallock (2000) discuss the changing stock price reaction to job loss announcements over time using data from 1970-97 and briefly discuss whether changes in technology have somehow made news less timely and therefore less "newsworthy." They find very little support for this hypothesis.
} 
reaction to strikes for entire industries and these effects are larger than those found in the aforementioned studies excepting Becker and Olson (1986) although, like the others, their focus was on the reactions of individual firms.

Given our concentration on industry returns, the magnitude of our estimates might be surprising, since we expect industry wide reactions to strikes to be smaller than the effect on specific firms (as business moves from struck to unstruck firms, for example). Moreover, our evidence is roughly consistent with Kramer and Vasconcellos (1996) who find effects on unstruck firms that are statistically indistinguishable from those on struck firms from 1982-1990. On the other hand, given our focus on the seminal industrial relations strikes of the inter-war period, our results are consistent with historians and others who have singled out this period as one of unusual importance in the development of postwar industrial relations.

\section{Concluding Comments}

The primary motivation of this work is to investigate the effect of strikes on industry stock prices at a time when unions were rapidly evolving. In contrast to recent work on the subject which has utilized data from the recent past, we look to a period of time where changes in the level of unionization were more important: it is easier to measure the effect of "large changes" than it is to detect small changes in the current era of declining unionization.

The time between the world wars (1925 - 1937) was particularly important in the history of unionization. Unlike many of the strikes of the current period, during this period of time many were an attempt by workers to change the "terms of trade" between workers and employers.

Our empirical approach melds two previous literatures: in one, the effects of strikes on industry wide measures of output, such as inventories, are studied, in the second, a 
standard "event study" approach is used to examine the relationship between strikes and individual firm stock valuations. In addition to developing a data set with a unusually rich set of characteristics for each of the strikes for the time period 1925-1937 and combining this information with stock return data, we use a very parsimonious model that helps provide (one) consistent interpretation of our results.

On a descriptive level, we find that strikes have large negative effects on industry stock valuation. In addition, longer strikes, violent strikes, strikes where the union wins, strikes that led to union recognition, industry wide strikes, and strikes that lead to wage increases affect industry stock prices more negatively than strikes with other characteristics. We also examine industry stock price movements around the start and the end of the strike. It seems that "news" about the strike seems to be revealed early - that is, there are much larger industry stock price reactions around the start of strikes than at the end.

In the context of our simple model, effects of successful strikes are quite important. The generally asymetric response of stock prices to wins and losses is consistent with the view that firms generally expected unions to lose. Despite this, the size of the effects when the union wins are consistent with the view that the effects of strikes were not limited to the single firm being struck, but felt industry wide by investors. Our analysis suggests that financial markets viewed union victories in the inter-war period as very important determinants of the share of firm profits going to stockholders. 


\section{References}

Abowd, John M., George T. Milkovich, and John M. Hannon, "The Effects of Human Resource Management Decisions on Shareholder Value," Industrial and Labor Relations Review, February 1990, 43 (3), 203S-236S.

Becker, Brian E. and Craig A. Olson, "The Impact of Strikes on Shareholder Equity," Industrial and Labor Relations Review, April 1986, 39 (3), 425-438.

Bound, John and George Johnson, "What are the Causes of Rising Inequality in the United States?," Economic Policy Review, January 1995, 1, 9-17.

Bronars, Stephen G. and Donald R. Deere, "Union Organizing Activity, Firm Growth, and the Business Cycle," American Economic Review, 1993, 83, 203-220.

Brown, James N. and Orley Ashenfelter, "Testing the Efficiency of Employment Contracts," Journal of Political Economy, 1986, 94, S40-S87.

Brown, Steven J. and Jerold B. Warner, "Measuring Security Price Returns," Journal of Financial Economics, March 1985, 14 (1), 3-31.

Campbell, John Y., Andrew W. Lo, and A. Craig MacKinlay, The Econometrics of Financial Markets, Princeton, NJ: Princeton University Press, 1997.

Card, David and Craig Olson, "Bargaining Power, Strike Durations, and Wage Outcomes - An Analysis of Strikes in the 1880s," Journal of Labor Economics, January 1995, $13(1), 32-61$.

Cowles, Alfred and Associates, Common-stock indexes Cowles Commission for Research in Economics Monograph No. 3, second ed., Bloomington, Indiana: Principia Press, Inc., 1938.

Davidson, Wallace N. III, Dan L. Worrell, and Sharon H. Garrison, "Effect of Strike Activity on Firm Value," Academy of Management Journal, 1988, 31 (2), $387-394$.

DiNardo, John, Kevin Hallock, and Jörn-Steffen Pischke, "Unions and Managerial Pay," NBER Working Paper 5607, National Bureau of Economic Research, Cambridge, MA June 1997.

Fama, Eugene, Lawrence Fisher, Michael Jensen, and Richard Roll, "The Adjustment of Stock Prices to New Information," International Economic Review, February $1969,10(1), 1-21$. 
Farber, Henry S. and Kevin F. Hallock, "Have Employment Reductions Become Good News for Shareholders? The Effect of Job Loss Announcements on Stock Prices, 1970-97," Working Paper, Princeton University and University of Illinois March 2000.

Filippelli, Ronald L., Labor conflict in the United States : an encyclopedia Garland reference library of social science, New York: Garland Publishing, 1990.

Fink, Gary M., Labor Unions The Greenwood Encyclopedia of American Institutions, Westport, Connecticut: Greenwood Press, 1977.

Fisher, Thomas R., Industrial Disputes and Federal Legislation, New York: Columbia University Press, 1940.

Freeman, Richard B. and James L. Medoff, "The Impact of the Percentage Organized on Union and Nonunion Wages," The Review of Economics and Statistics, November 1981, $63(4), 561-572$.

_ and _ What Do Unions Do?, New York: Basic Books, 1984.

Gifford, Court, Directory of U.S. Labor Organizations, Washington, D.C.: Bureau of National Affairs, Inc., 1999.

Griffin, John Ignatius, Strikes: A Study in Quantatative Economics, New York: Columbia University Press, 1939.

Kramer, Jonathan K. and Geraldo M. Vasconcellos, "The Economic Effect of Strikes on the Shareholders of Nonstruck Competitors," Industrial and Labor Relations Review, January 1996, 49 (2), 213-222.

Kremer, Michael, "An Epidemiological Model of Unions," Unpublished Manuscript, Massachusetts Institute of Technology, May 1999.

Lazear, Edward, "A Competitive Theory of Monopoly Unionism," American Economic Review, September 1983, 73 (4), 631-643.

Leicht, Kevin T., "On the Estimation of Union Threat Effects," American Sociological Review, December 1989, 54 (6), 1035-1047.

MacKinlay, A. Craig, "Event studies in economics and finance," Journal of Economic Literature, March 1997, 35 (1), 13-39.

MaCurdy, Thomas and John Pencavel, "Testing the Efficiency of Employment Contracts," Journal of Political Economy, 1986, 94, S3-S39. 
Nelson, Morton, Ben Amoako-Adu, and Brian Smith, "Impact of Labor Strikes on Equity Values: Canadian Evidence," Journal of Economics and Business, 1994, 46, 153-165.

Neumann, George R., "The Predictability of Strikes: Evidence from the Stock Market," Industrial and Labor Relations Review, July 1990, 33 (4), 535-535.

and Melvin W. Reder, "Output and Strike Activity in U.S. Manufacturing: How Large Are the Losses?," Industrial and Labor Relations Review, January 1984, 37 (2), $197-211$.

Neumark, David and Michael Wachter, "Union Threat Effects and Nonunion Industry Wage Differentials," Industrial and Labor Relations Review, 1995, 48, 20-38.

Persons, Obeua S., "The Effects of Automobile Strikes on the Stock Value of Steel Suppliers," Industrial and Labor Relations Review, October 1995, 49 (1), 78-87.

Peterson, Florence, Strikes in the United States, 1880-1936 number 651. In 'Bulletin of the United States Bureau of Labor Statistics.', Washington, D.C.: United States Government Printing Office, 1938.

Rees, A., The Economics of Trade Unions, Chicago: University of Chicago Press, 1977.

Reynolds, Lloyd G. and Charles C. Killingsworth, Trade Union Publications: The Official Journals, Convention Proceedings, and Constitutions of International Unions and Federations, 1850-1941, Vol. 1, Baltimore: The Johns Hopkins Press, 1944.

Ruback, Richard and Martin Zimmerman, "Unionization and Profitability: Evidence from the Capital Market," Journal of Political Economy, 1984, 92, 1134-1157.

Rubin, Beth A., "Class Struggle American Style: Unions, Strikes, and Wages," American Sociological Review, October 1986, 51, 618-631. 
TABLE 1: Sample Statistics for the Strikes

\begin{tabular}{|c|c|c|c|c|c|c|c|}
\hline Industry & $\begin{array}{l}\text { Start Date } \\
\text { of Strike }\end{array}$ & $\begin{array}{c}\text { Strike } \\
\text { Duration } \\
\text { (months) }\end{array}$ & $\begin{array}{c}\text { Number } \\
\text { of } \\
\text { Strikers }\end{array}$ & $\begin{array}{c}\text { Violence } \\
\text { During } \\
\text { Strike? }\end{array}$ & $\begin{array}{c}\text { Recog- } \\
\text { nition } \\
\text { Strike? }\end{array}$ & $\begin{array}{c}\text { Wages Inc., Decr. } \\
\text { or Same }\end{array}$ & Winner \\
\hline \multirow[t]{5}{*}{ Coal } & Nov 1925 & 5 & 500 & No & No & Decreased & Unclear \\
\hline & Apr 1927 & 15 & 200000 & Yes & No & Same & Mgt. \\
\hline & Apr 1931 & 1 & 200 & Yes & No & Same & Mgt. \\
\hline & Jul 1932 & 11 & -- & Yes & No & Decreased & Mgt. \\
\hline & Aug 1933 & 3 & 2000 & No & No & Same & Mgt. \\
\hline \multirow[t]{2}{*}{ Misc. Services } & May 1934 & 3 & 3000 & Yes & No & Increased & Union \\
\hline & May 1935 & 3 & 20000 & Yes & No & Increased & Union \\
\hline \multirow[t]{2}{*}{ Shipping } & May 1934 & 2 & 1000 & Yes & No & Increased & Union \\
\hline & Jan 1936 & 12 & 30000 & No & No & Increased & Unclear \\
\hline Mining & May 1935 & 1 & -- & Yes & No & Same & Mgt. \\
\hline Steel and Iron & May 1937 & 2 & 40000 & Yes & No & Same & Mgt. \\
\hline Electrical Equip & Feb 1934 & 4 & 3600 & Yes & Yes & Increased & Union \\
\hline Household Products & -- & -- & 1000 & No & Yes & Decreased & Mgt. \\
\hline \multirow[t]{2}{*}{ Auto Tires, Rubber } & Jun 1934 & 1 & 1100 & No & Yes & Increased & Union \\
\hline & Jan 1936 & 2 & 14000 & No & Yes & Same & Union \\
\hline \multirow[t]{7}{*}{ Food Products } & Jan 1930 & 0 & 5000 & Yes & No & Same & Mgt. \\
\hline & Nov 1932 & 2 & 400 & Yes & No & Decreased & Mgt. \\
\hline & May 1932 & 50 & 1500 & No & No & Same & Mgt. \\
\hline & Jan 1933 & 0 & 5000 & Yes & No & Same & Mgt. \\
\hline & Sep 1935 & 1 & -- & Yes & No & Increased & Union \\
\hline & May 1936 & -- & 35000 & Yes & No & Same & Mgt. \\
\hline & May 1937 & 0 & 2000 & Yes & Yes & Same & Mgt. \\
\hline \multirow[t]{3}{*}{ Paper } & Nov 1934 & 4 & 36 & No & No & Same & Union \\
\hline & -- & -- & 600 & No & No & Same & Union \\
\hline & Feb 1936 & 9 & 36 & No & No & Increased & Union \\
\hline \multirow[t]{5}{*}{ Textiles } & Jan 1925 & 23 & 16000 & Yes & Yes & Same & Union \\
\hline & Apr 1928 & 6 & 27000 & Yes & Yes & Decreased & Union \\
\hline & Apr 1929 & 5 & 1000 & Yes & No & Same & Mgt. \\
\hline & Jul 1934 & 2 & -- & Yes & No & Same & Unclear \\
\hline & Oct 1936 & 5 & 3700 & No & No & Same & Mgt. \\
\hline Tobacco & Nov 1931 & 1 & 10000 & No & No & Same & Union \\
\hline \multirow[t]{4}{*}{ General Motors } & Sep 1933 & 2 & 5000 & No & No & Increased & Unclear \\
\hline & Nov 1936 & -- & -- & No & No & -- & -- \\
\hline & Dec 1936 & 2 & 47000 & Yes & Yes & Same & Union \\
\hline & -- & -- & 7600 & No & Yes & Increased & Union \\
\hline \multirow[t]{3}{*}{ Autos, non-GM } & Jan 1933 & 1 & 12000 & No & No & Increased & Union \\
\hline & -- & -- & 24000 & No & No & Same & Union \\
\hline & -- & -- & 2000 & Yes & Yes & Same & Union \\
\hline Meat Packing & Sep 1933 & -- & -- & Yes & Yes & Increased & Union \\
\hline Radio, Phonograph & May 1936 & 2 & 6000 & Yes & Yes & Increased & Union \\
\hline Air Transport & Feb 1932 & 3 & 36 & No & No & Increased & Union \\
\hline
\end{tabular}

Notes: This information was gathered from narratives in Filippelli (1990). 
TABLE 2. Cumulative Average Abnormal Industry Stock Returns for Strikes in 1920s and 1930s where event is defined as start of strike (t-statistics are in parentheses)

\begin{tabular}{|c|c|c|c|c|c|c|}
\hline \multirow[b]{3}{*}{ all strikes } & \multicolumn{6}{|c|}{ Months Relative to Strike Announcement Date } \\
\hline & $\mathrm{t}=0$ & $\mathrm{t}=0$ to 1 & $\mathrm{t}=-1$ to 0 & $\mathrm{t}=-1$ to 1 & $\mathrm{t}=-2$ to 2 & $\mathrm{t}=-3$ to 3 \\
\hline & $\begin{array}{l}-0.011 \\
(1.070)\end{array}$ & $\begin{array}{c}-0.024 \\
(1.580)\end{array}$ & $\begin{array}{c}-0.017 \\
(1.172)\end{array}$ & $\begin{array}{c}-0.030 \\
(1.635)\end{array}$ & $\begin{array}{c}-0.013 \\
(0.539)\end{array}$ & $\begin{array}{l}-0.015 \\
(0.559)\end{array}$ \\
\hline union win & $\begin{array}{l}-0.020 \\
(1.034)\end{array}$ & $\begin{array}{c}-0.050 \\
(1.845)\end{array}$ & $\begin{array}{c}-0.038 \\
(1.418)\end{array}$ & $\begin{array}{l}-0.068 \\
(2.067)\end{array}$ & $\begin{array}{c}-0.038 \\
(0.891)\end{array}$ & $\begin{array}{l}-0.020 \\
(0.390)\end{array}$ \\
\hline union loss & $\begin{array}{l}-0.004 \\
(0.312)\end{array}$ & $\begin{array}{c}-0.004 \\
(0.218)\end{array}$ & $\begin{array}{l}-0.007 \\
(0.475)\end{array}$ & $\begin{array}{l}-0.008 \\
(0.373)\end{array}$ & $\begin{array}{c}0.007 \\
(0.255)\end{array}$ & $\begin{array}{l}-0.016 \\
(0.536)\end{array}$ \\
\hline yes violence & $\begin{array}{l}-0.019 \\
(1.616)\end{array}$ & $\begin{array}{c}-0.025 \\
(1.455)\end{array}$ & $\begin{array}{l}-0.033 \\
(2.037)\end{array}$ & $\begin{array}{l}-0.040 \\
(1.909)\end{array}$ & $\begin{array}{l}-0.049 \\
(1.855)\end{array}$ & $\begin{array}{l}-0.049 \\
(1.588)\end{array}$ \\
\hline no violence & $\begin{array}{c}0.001 \\
(0.059)\end{array}$ & $\begin{array}{c}-0.021 \\
(0.775)\end{array}$ & $\begin{array}{c}0.008 \\
(0.307)\end{array}$ & $\begin{array}{l}-0.014 \\
(0.415)\end{array}$ & $\begin{array}{c}0.044 \\
(1.031)\end{array}$ & $\begin{array}{c}0.038 \\
(0.736)\end{array}$ \\
\hline wages down & $\begin{array}{c}0.037 \\
(1.916)\end{array}$ & $\begin{array}{c}0.092 \\
(2.096)\end{array}$ & $\begin{array}{c}0.032 \\
(1.159)\end{array}$ & $\begin{array}{c}0.087 \\
(1.814)\end{array}$ & $\begin{array}{c}0.128 \\
(2.264)\end{array}$ & $\begin{array}{c}0.095 \\
(1.478)\end{array}$ \\
\hline wages same & $\begin{array}{l}-0.014 \\
(1.094)\end{array}$ & $\begin{array}{l}-0.038 \\
(2.066)\end{array}$ & $\begin{array}{l}-0.027 \\
(1.430)\end{array}$ & $\begin{array}{l}-0.050 \\
(2.222)\end{array}$ & $\begin{array}{l}-0.052 \\
(1.763)\end{array}$ & $\begin{array}{l}-0.061 \\
(1.750)\end{array}$ \\
\hline wages up & $\begin{array}{l}-0.016 \\
(0.804)\end{array}$ & $\begin{array}{c}-0.031 \\
(1.085)\end{array}$ & $\begin{array}{l}-0.014 \\
(0.473)\end{array}$ & $\begin{array}{l}-0.029 \\
(0.807)\end{array}$ & $\begin{array}{c}0.016 \\
(0.344)\end{array}$ & $\begin{array}{c}0.040 \\
(0.732)\end{array}$ \\
\hline many strikers $^{(a)}$ & $\begin{array}{l}-0.013 \\
(1.068)\end{array}$ & $\begin{array}{l}-0.016 \\
(0.949)\end{array}$ & $\begin{array}{l}-0.005 \\
(0.324)\end{array}$ & $\begin{array}{l}-0.008 \\
(0.417)\end{array}$ & $\begin{array}{l}-0.015 \\
(0.575)\end{array}$ & $\begin{array}{l}-0.022 \\
(0.716)\end{array}$ \\
\hline few strikers & $\begin{array}{l}-0.012 \\
(0.674)\end{array}$ & $\begin{array}{c}-0.041 \\
(1.636)\end{array}$ & $\begin{array}{c}-0.026 \\
(1.037)\end{array}$ & $\begin{array}{l}-0.056 \\
(1.792)\end{array}$ & $\begin{array}{c}-0.005 \\
(0.123)\end{array}$ & $\begin{array}{c}0.008 \\
(0.160)\end{array}$ \\
\hline short strike $e^{(b)}$ & $\begin{array}{l}-0.000 \\
(0.001)\end{array}$ & $\begin{array}{l}-0.004 \\
(0.172)\end{array}$ & $\begin{array}{c}-0.006 \\
(0.268)\end{array}$ & $\begin{array}{l}-0.010 \\
(0.352)\end{array}$ & $\begin{array}{c}0.047 \\
(1.242)\end{array}$ & $\begin{array}{c}0.045 \\
(1.009)\end{array}$ \\
\hline long strike & $\begin{array}{l}-0.019 \\
(1.435)\end{array}$ & $\begin{array}{c}-0.036 \\
(1.920)\end{array}$ & $\begin{array}{c}-0.024 \\
(1.285)\end{array}$ & $\begin{array}{l}-0.041 \\
(1.786)\end{array}$ & $\begin{array}{c}-0.048 \\
(1.661)\end{array}$ & $\begin{array}{c}-0.052 \\
(1.494)\end{array}$ \\
\hline recognition & $\begin{array}{l}-0.037 \\
(1.642)\end{array}$ & $\begin{array}{c}-0.061 \\
(1.933)\end{array}$ & $\begin{array}{l}-0.041 \\
(1.292)\end{array}$ & $\begin{array}{c}-0.065 \\
(1.683)\end{array}$ & $\begin{array}{c}-0.088 \\
(1.764)\end{array}$ & $\begin{array}{c}-0.091 \\
(1.535)\end{array}$ \\
\hline not recognition & $\begin{array}{l}-0.001 \\
(0.088)\end{array}$ & $\begin{array}{l}-0.010 \\
(0.546)\end{array}$ & $\begin{array}{c}-0.008 \\
(0.484)\end{array}$ & $\begin{array}{l}-0.016 \\
(0.787)\end{array}$ & $\begin{array}{c}0.017 \\
(0.643)\end{array}$ & $\begin{array}{c}0.014 \\
(0.448)\end{array}$ \\
\hline industry wide & $\begin{array}{l}-0.021 \\
(0.650)\end{array}$ & $\begin{array}{l}-0.040 \\
(0.871)\end{array}$ & $\begin{array}{l}-0.051 \\
(1.125)\end{array}$ & $\begin{array}{l}-0.070 \\
(1.254)\end{array}$ & $\begin{array}{c}-0.109 \\
(1.515)\end{array}$ & $\begin{array}{l}-0.125 \\
(1.461)\end{array}$ \\
\hline not industry wide & $\begin{array}{l}-0.010 \\
(0.931)\end{array}$ & $\begin{array}{c}-0.022 \\
(1.403)\end{array}$ & $\begin{array}{c}-0.014 \\
(0.908)\end{array}$ & $\begin{array}{l}-0.026 \\
(1.358)\end{array}$ & $\begin{array}{c}-0.004 \\
(0.151)\end{array}$ & $\begin{array}{l}-0.005 \\
(0.188)\end{array}$ \\
\hline new union ${ }^{(\mathrm{c})}$ & $\begin{array}{l}-0.002 \\
(0.080)\end{array}$ & $\begin{array}{l}-0.015 \\
(0.487)\end{array}$ & $\begin{array}{c}-0.008 \\
(0.247)\end{array}$ & $\begin{array}{l}-0.021 \\
(0.553)\end{array}$ & $\begin{array}{c}0.059 \\
(1.179)\end{array}$ & $\begin{array}{c}0.057 \\
(0.963)\end{array}$ \\
\hline old union & $\begin{array}{l}-0.011 \\
(0.909)\end{array}$ & $\begin{array}{l}-0.016 \\
(0.829)\end{array}$ & $\begin{array}{c}-0.019 \\
(1.157)\end{array}$ & $\begin{array}{c}-0.024 \\
(1.088)\end{array}$ & $\begin{array}{c}-0.049 \\
(1.747)\end{array}$ & $\begin{array}{l}-0.059 \\
(1.817)\end{array}$ \\
\hline
\end{tabular}

Notes: For description of the strikes and the stock price data see table 1.

(a) Above the median of 3700 strikers. (b) Below the median of 2 months. (c) Less than 3 years old. 
TABLE 3. Cumulative Average Abnormal Industry Stock Returns for Strikes in 1920s and 1930s where event is defined as End of Strike (t-statistics are in parentheses)

\begin{tabular}{|c|c|c|c|c|c|c|}
\hline \multirow[b]{3}{*}{ all strikes } & \multicolumn{6}{|c|}{ Months Relative to Strike Ending Date } \\
\hline & $t=0$ & $\mathrm{t}=0$ to 1 & $\mathrm{t}=-1$ to 0 & $\mathrm{t}=-1$ to 1 & $\mathrm{t}=-2$ to 2 & $\mathrm{t}=-3$ to 3 \\
\hline & $\begin{array}{l}-0.001 \\
(0.061)\end{array}$ & $\begin{array}{c}0.009 \\
(0.589)\end{array}$ & $\begin{array}{c}0.011 \\
(0.725)\end{array}$ & $\begin{array}{c}0.020 \\
(1.107)\end{array}$ & $\begin{array}{c}0.013 \\
(0.565)\end{array}$ & $\begin{array}{l}-0.007 \\
(0.238)\end{array}$ \\
\hline union win & $\begin{array}{l}-0.006 \\
(0.310)\end{array}$ & $\begin{array}{c}0.009 \\
(0.353)\end{array}$ & $\begin{array}{c}0.021 \\
(0.781)\end{array}$ & $\begin{array}{c}0.036 \\
(1.104)\end{array}$ & $\begin{array}{c}0.012 \\
(0.285)\end{array}$ & $\begin{array}{l}-0.051 \\
(0.991)\end{array}$ \\
\hline union loss & $\begin{array}{c}0.001 \\
(0.055)\end{array}$ & $\begin{array}{l}-0.000 \\
(0.012)\end{array}$ & $\begin{array}{c}-0.001 \\
(0.036)\end{array}$ & $\begin{array}{l}-0.001 \\
(0.070)\end{array}$ & $\begin{array}{c}0.006 \\
(0.225)\end{array}$ & $\begin{array}{c}0.016 \\
(0.501)\end{array}$ \\
\hline yes violence & $\begin{array}{l}-0.003 \\
(0.276)\end{array}$ & $\begin{array}{l}-0.011 \\
(0.700)\end{array}$ & $\begin{array}{l}-0.008 \\
(0.462)\end{array}$ & $\begin{array}{l}-0.016 \\
(0.786)\end{array}$ & $\begin{array}{l}-0.030 \\
(1.129)\end{array}$ & $\begin{array}{l}-0.057 \\
(1.813)\end{array}$ \\
\hline no violence & $\begin{array}{c}0.003 \\
(0.169)\end{array}$ & $\begin{array}{c}0.040 \\
(1.432)\end{array}$ & $\begin{array}{c}0.039 \\
(1.413)\end{array}$ & $\begin{array}{c}0.076 \\
(2.223)\end{array}$ & $\begin{array}{c}0.080 \\
(1.817)\end{array}$ & $\begin{array}{c}0.070 \\
(1.303)\end{array}$ \\
\hline wages down & $\begin{array}{c}0.081 \\
(3.629)\end{array}$ & $\begin{array}{c}0.092 \\
(3.034)\end{array}$ & $\begin{array}{c}0.119 \\
(3.421)\end{array}$ & $\begin{array}{c}0.130 \\
(3.221)\end{array}$ & $\begin{array}{c}0.156 \\
(3.216)\end{array}$ & $\begin{array}{c}0.153 \\
(2.760)\end{array}$ \\
\hline wages same & $\begin{array}{l}-0.013 \\
(0.962)\end{array}$ & $\begin{array}{l}-0.014 \\
(0.778)\end{array}$ & $\begin{array}{l}-0.018 \\
(0.994)\end{array}$ & $\begin{array}{l}-0.020 \\
(0.892)\end{array}$ & $\begin{array}{l}-0.022 \\
(0.749)\end{array}$ & $\begin{array}{l}-0.016 \\
(0.464)\end{array}$ \\
\hline wages up & $\begin{array}{l}-0.011 \\
(0.531)\end{array}$ & $\begin{array}{c}0.013 \\
(0.459)\end{array}$ & $\begin{array}{c}0.016 \\
(0.543)\end{array}$ & $\begin{array}{c}0.040 \\
(1.121)\end{array}$ & $\begin{array}{c}0.016 \\
(0.348)\end{array}$ & $\begin{array}{l}-0.046 \\
(0.809)\end{array}$ \\
\hline many strikers $^{(a)}$ & $\begin{array}{l}-0.001 \\
(0.089)\end{array}$ & $\begin{array}{c}0.002 \\
(0.091)\end{array}$ & $\begin{array}{l}-0.008 \\
(0.455)\end{array}$ & $\begin{array}{l}-0.005 \\
(0.250)\end{array}$ & $\begin{array}{c}0.000 \\
(0.013)\end{array}$ & $\begin{array}{c}0.002 \\
(0.062)\end{array}$ \\
\hline few strikers & $\begin{array}{l}-0.014 \\
(0.760)\end{array}$ & $\begin{array}{c}0.003 \\
(0.098)\end{array}$ & $\begin{array}{c}0.009 \\
(0.329)\end{array}$ & $\begin{array}{c}0.025 \\
(0.785)\end{array}$ & $\begin{array}{c}0.009 \\
(0.215)\end{array}$ & $\begin{array}{c}-0.032 \\
(0.632)\end{array}$ \\
\hline short strike ${ }^{(b)}$ & $\begin{array}{c}0.018 \\
(1.147)\end{array}$ & $\begin{array}{c}0.041 \\
(1.924)\end{array}$ & $\begin{array}{c}0.055 \\
(2.470)\end{array}$ & $\begin{array}{c}0.079 \\
(2.927)\end{array}$ & $\begin{array}{c}0.077 \\
(2.231)\end{array}$ & $\begin{array}{c}0.029 \\
(0.682)\end{array}$ \\
\hline long strike & $\begin{array}{l}-0.018 \\
(1.243)\end{array}$ & $\begin{array}{c}-0.022 \\
(1.099)\end{array}$ & $\begin{array}{c}-0.030 \\
(1.510)\end{array}$ & $\begin{array}{l}-0.035 \\
(1.413)\end{array}$ & $\begin{array}{c}-0.046 \\
(1.433)\end{array}$ & $\begin{array}{l}-0.040 \\
(1.037)\end{array}$ \\
\hline recognition & $\begin{array}{c}-0.022 \\
(1.084)\end{array}$ & $\begin{array}{c}-0.023 \\
(0.814)\end{array}$ & $\begin{array}{c}-0.031 \\
(1.101)\end{array}$ & $\begin{array}{c}-0.033 \\
(0.939)\end{array}$ & $\begin{array}{l}-0.035 \\
(0.782)\end{array}$ & $\begin{array}{l}-0.085 \\
(1.591)\end{array}$ \\
\hline not recognition & $\begin{array}{c}0.007 \\
(0.597)\end{array}$ & $\begin{array}{c}0.021 \\
(1.197)\end{array}$ & $\begin{array}{c}0.027 \\
(1.517)\end{array}$ & $\begin{array}{c}0.040 \\
(1.873)\end{array}$ & $\begin{array}{c}0.032 \\
(1.144)\end{array}$ & $\begin{array}{c}0.023 \\
(0.679)\end{array}$ \\
\hline industry wide & $\begin{array}{l}-0.046 \\
(1.034)\end{array}$ & $\begin{array}{c}-0.086 \\
(1.379)\end{array}$ & $\begin{array}{l}-0.071 \\
(1.132)\end{array}$ & $\begin{array}{l}-0.111 \\
(1.454)\end{array}$ & $\begin{array}{c}-0.153 \\
(1.546)\end{array}$ & $\begin{array}{l}-0.217 \\
(1.854)\end{array}$ \\
\hline not industry wide & $\begin{array}{c}0.004 \\
(0.364)\end{array}$ & $\begin{array}{c}0.018 \\
(1.214)\end{array}$ & $\begin{array}{c}0.019 \\
(1.250)\end{array}$ & $\begin{array}{c}0.033 \\
(1.800)\end{array}$ & $\begin{array}{c}0.030 \\
(1.251)\end{array}$ & $\begin{array}{c}0.014 \\
(0.492)\end{array}$ \\
\hline new union ${ }^{(\mathrm{c})}$ & $\begin{array}{c}0.024 \\
(0.986)\end{array}$ & $\begin{array}{c}0.085 \\
(2.453)\end{array}$ & $\begin{array}{c}0.084 \\
(2.396)\end{array}$ & $\begin{array}{c}0.144 \\
(3.387)\end{array}$ & $\begin{array}{c}0.131 \\
(2.360)\end{array}$ & $\begin{array}{c}0.069 \\
(1.011)\end{array}$ \\
\hline old union & $\begin{array}{l}-0.007 \\
(0.528)\end{array}$ & $\begin{array}{l}-0.016 \\
(0.866)\end{array}$ & $\begin{array}{c}-0.023 \\
(1.178)\end{array}$ & $\begin{array}{l}-0.032 \\
(1.365)\end{array}$ & $\begin{array}{l}-0.040 \\
(1.309)\end{array}$ & $\begin{array}{c}-0.063 \\
(1.739)\end{array}$ \\
\hline
\end{tabular}

Notes: For description of the strikes and the stock price data see table 1.

(a) Above the median of 3700 strikers. (b) Below the median of 2 months. (c) Less than 3 years old. 
TABLE 4. Cumulative Average Abnormal Industry Stock Returns for Strikes in 1920s and 1930s: Addition of Returns Around Start of Strike and End of Strike (t-statistics are in parentheses)

\begin{tabular}{|c|c|c|c|c|c|c|}
\hline \multirow[b]{3}{*}{ all strikes } & \multicolumn{6}{|c|}{ Months Relative to Strike Starting and Ending Date } \\
\hline & $\mathrm{t}=0$ & $\mathrm{t}=0$ to 1 & $\mathrm{t}=-1$ to 0 & $t=-1$ to 1 & $t=-2$ to 2 & $t=-3$ to 3 \\
\hline & $\begin{array}{c}-0.012 \\
(1.072)\end{array}$ & $\begin{array}{c}-0.015 \\
(1.686)\end{array}$ & $\begin{array}{c}-0.006 \\
(1.378)\end{array}$ & $\begin{array}{l}-0.010 \\
(1.975)\end{array}$ & $\begin{array}{c}0.000 \\
(0.781)\end{array}$ & $\begin{array}{l}-0.022 \\
(0.608)\end{array}$ \\
\hline union win & $\begin{array}{l}-0.026 \\
(1.079)\end{array}$ & $\begin{array}{c}-0.041 \\
(1.878)\end{array}$ & $\begin{array}{c}-0.017 \\
(1.619)\end{array}$ & $\begin{array}{l}-0.032 \\
(2.343)\end{array}$ & $\begin{array}{c}-0.026 \\
(0.935)\end{array}$ & $\begin{array}{c}-0.071 \\
(1.065)\end{array}$ \\
\hline union loss & $\begin{array}{l}-0.003 \\
(0.317)\end{array}$ & $\begin{array}{c}-0.004 \\
(0.218)\end{array}$ & $\begin{array}{c}-0.008 \\
(0.476)\end{array}$ & $\begin{array}{c}-0.009 \\
(0.380)\end{array}$ & $\begin{array}{c}0.013 \\
(0.340)\end{array}$ & $\begin{array}{c}0.000 \\
(0.734)\end{array}$ \\
\hline yes violence & $\begin{array}{l}-0.021 \\
(1.639)\end{array}$ & $\begin{array}{c}-0.036 \\
(1.615)\end{array}$ & $\begin{array}{l}-0.041 \\
(2.089)\end{array}$ & $\begin{array}{l}-0.056 \\
(2.064)\end{array}$ & $\begin{array}{c}-0.079 \\
(2.172)\end{array}$ & $\begin{array}{c}-0.106 \\
(2.410)\end{array}$ \\
\hline no violence & $\begin{array}{c}0.004 \\
(0.179)\end{array}$ & $\begin{array}{c}0.019 \\
(1.629)\end{array}$ & $\begin{array}{c}0.047 \\
(1.446)\end{array}$ & $\begin{array}{c}0.062 \\
(2.261)\end{array}$ & $\begin{array}{c}0.124 \\
(2.089)\end{array}$ & $\begin{array}{c}0.108 \\
(1.496)\end{array}$ \\
\hline wages down & $\begin{array}{c}0.118 \\
(4.105)\end{array}$ & $\begin{array}{c}0.184 \\
(3.688)\end{array}$ & $\begin{array}{c}0.151 \\
(3.612)\end{array}$ & $\begin{array}{c}0.217 \\
(3.697)\end{array}$ & $\begin{array}{c}0.284 \\
(3.933)\end{array}$ & $\begin{array}{c}0.248 \\
(3.131)\end{array}$ \\
\hline wages same & $\begin{array}{l}-0.027 \\
(1.457)\end{array}$ & $\begin{array}{c}-0.052 \\
(2.208)\end{array}$ & $\begin{array}{c}-0.045 \\
(1.742)\end{array}$ & $\begin{array}{l}-0.070 \\
(2.394)\end{array}$ & $\begin{array}{c}-0.074 \\
(1.916)\end{array}$ & $\begin{array}{c}-0.077 \\
(1.810)\end{array}$ \\
\hline wages up & $\begin{array}{l}-0.027 \\
(0.964)\end{array}$ & $\begin{array}{c}-0.018 \\
(1.178)\end{array}$ & $\begin{array}{c}0.002 \\
(0.720)\end{array}$ & $\begin{array}{c}0.011 \\
(1.381)\end{array}$ & $\begin{array}{c}0.032 \\
(2.262)\end{array}$ & $\begin{array}{c}-0.006 \\
(0.085)\end{array}$ \\
\hline many strikers ${ }^{(a)}$ & $\begin{array}{l}-0.014 \\
(1.934)\end{array}$ & $\begin{array}{c}-0.014 \\
(1.043)\end{array}$ & $\begin{array}{c}-0.013 \\
(0.898)\end{array}$ & $\begin{array}{l}-0.013 \\
(0.543)\end{array}$ & $\begin{array}{l}-0.015 \\
(0.993)\end{array}$ & $\begin{array}{l}-0.020 \\
(0.722)\end{array}$ \\
\hline few strikers & $\begin{array}{l}-0.026 \\
(0.680)\end{array}$ & $\begin{array}{c}-0.038 \\
(1.639)\end{array}$ & $\begin{array}{c}-0.017 \\
(1.132)\end{array}$ & $\begin{array}{c}-0.031 \\
(1.809)\end{array}$ & $\begin{array}{c}0.004 \\
(0.124)\end{array}$ & $\begin{array}{c}-0.024 \\
(0.172)\end{array}$ \\
\hline short strike $e^{(b)}$ & $\begin{array}{c}0.018 \\
(0.760)\end{array}$ & $\begin{array}{c}0.037 \\
(0.198)\end{array}$ & $\begin{array}{c}0.049 \\
(0.424)\end{array}$ & $\begin{array}{c}0.069 \\
(0.860)\end{array}$ & $\begin{array}{c}0.124 \\
(1.260)\end{array}$ & $\begin{array}{c}0.074 \\
(1.191)\end{array}$ \\
\hline long strike & $\begin{array}{l}-0.037 \\
(1.837)\end{array}$ & $\begin{array}{l}-0.058 \\
(2.718)\end{array}$ & $\begin{array}{c}-0.054 \\
(2.784)\end{array}$ & $\begin{array}{l}-0.076 \\
(3.429)\end{array}$ & $\begin{array}{c}-0.094 \\
(2.781)\end{array}$ & $\begin{array}{l}-0.092 \\
(1.642)\end{array}$ \\
\hline recognition & $\begin{array}{l}-0.059 \\
(1.968)\end{array}$ & $\begin{array}{l}-0.084 \\
(2.097)\end{array}$ & $\begin{array}{c}-0.072 \\
(1.697)\end{array}$ & $\begin{array}{c}-0.098 \\
(1.927)\end{array}$ & $\begin{array}{c}-0.123 \\
(1.930)\end{array}$ & $\begin{array}{l}-0.176 \\
(2.211)\end{array}$ \\
\hline not recognition & $\begin{array}{c}0.006 \\
(0.603)\end{array}$ & $\begin{array}{c}0.011 \\
(1.316)\end{array}$ & $\begin{array}{c}0.019 \\
(1.592)\end{array}$ & $\begin{array}{c}0.024 \\
(2.032)\end{array}$ & $\begin{array}{c}0.049 \\
(1.312)\end{array}$ & $\begin{array}{c}0.037 \\
(0.813)\end{array}$ \\
\hline industry wide & $\begin{array}{l}-0.067 \\
(1.221)\end{array}$ & $\begin{array}{c}-0.126 \\
(1.631)\end{array}$ & $\begin{array}{c}-0.122 \\
(1.596)\end{array}$ & $\begin{array}{c}-0.181 \\
(1.920)\end{array}$ & $\begin{array}{l}-0.262 \\
(2.165)\end{array}$ & $\begin{array}{c}-0.342 \\
(2.360)\end{array}$ \\
\hline not industry wide & $\begin{array}{l}-0.006 \\
(1.000)\end{array}$ & $\begin{array}{c}-0.004 \\
(1.855)\end{array}$ & $\begin{array}{c}0.005 \\
(1.545)\end{array}$ & $\begin{array}{c}0.007 \\
(2.255)\end{array}$ & $\begin{array}{c}0.026 \\
(1.260)\end{array}$ & $\begin{array}{c}0.009 \\
(0.527)\end{array}$ \\
\hline new union ${ }^{(\mathrm{c})}$ & $\begin{array}{c}0.022 \\
(0.989)\end{array}$ & $\begin{array}{c}0.070 \\
(2.501)\end{array}$ & $\begin{array}{c}0.076 \\
(2.409)\end{array}$ & $\begin{array}{c}0.123 \\
(3.432)\end{array}$ & $\begin{array}{c}0.190 \\
(2.638)\end{array}$ & $\begin{array}{c}0.126 \\
(1.396)\end{array}$ \\
\hline old union & $\begin{array}{l}-0.018 \\
(1.051)\end{array}$ & $\begin{array}{l}-0.032 \\
(1.199)\end{array}$ & $\begin{array}{c}-0.042 \\
(1.651)\end{array}$ & $\begin{array}{l}-0.056 \\
(1.746)\end{array}$ & $\begin{array}{c}-0.089 \\
(2.183)\end{array}$ & $\begin{array}{l}-0.122 \\
(2.515)\end{array}$ \\
\hline
\end{tabular}

Notes: For description of the strikes and the stock price data see table 1.

(a) Above the median of 3700 strikers. (b) Below the median of 2 months. (c) Less than 3 years old. 
Figure 1: Fraction of Strikes where Union Succeeded, Failed, or there was a Compromise, 1880-1937 From Griffin (1939), Table XI.7

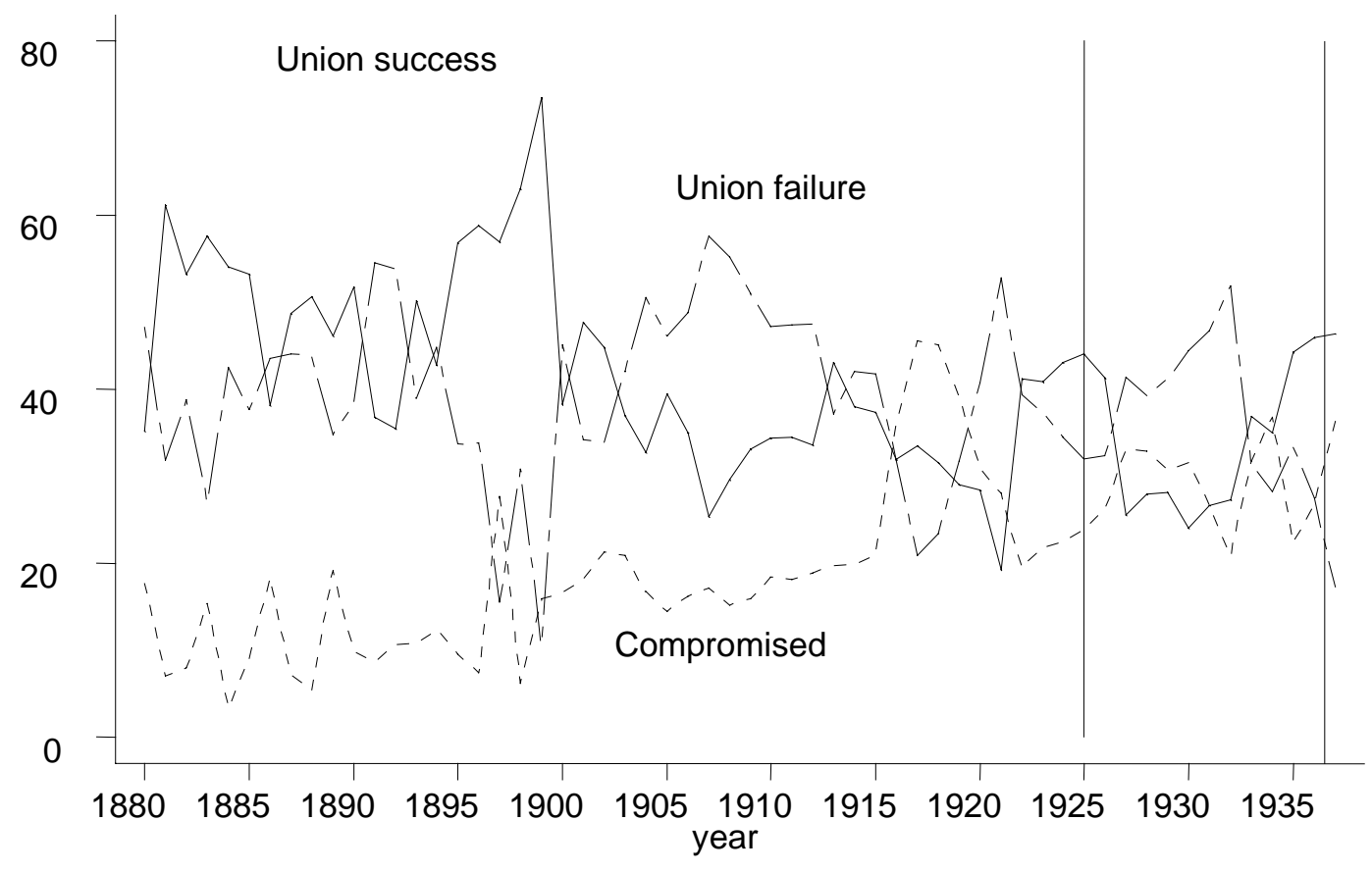




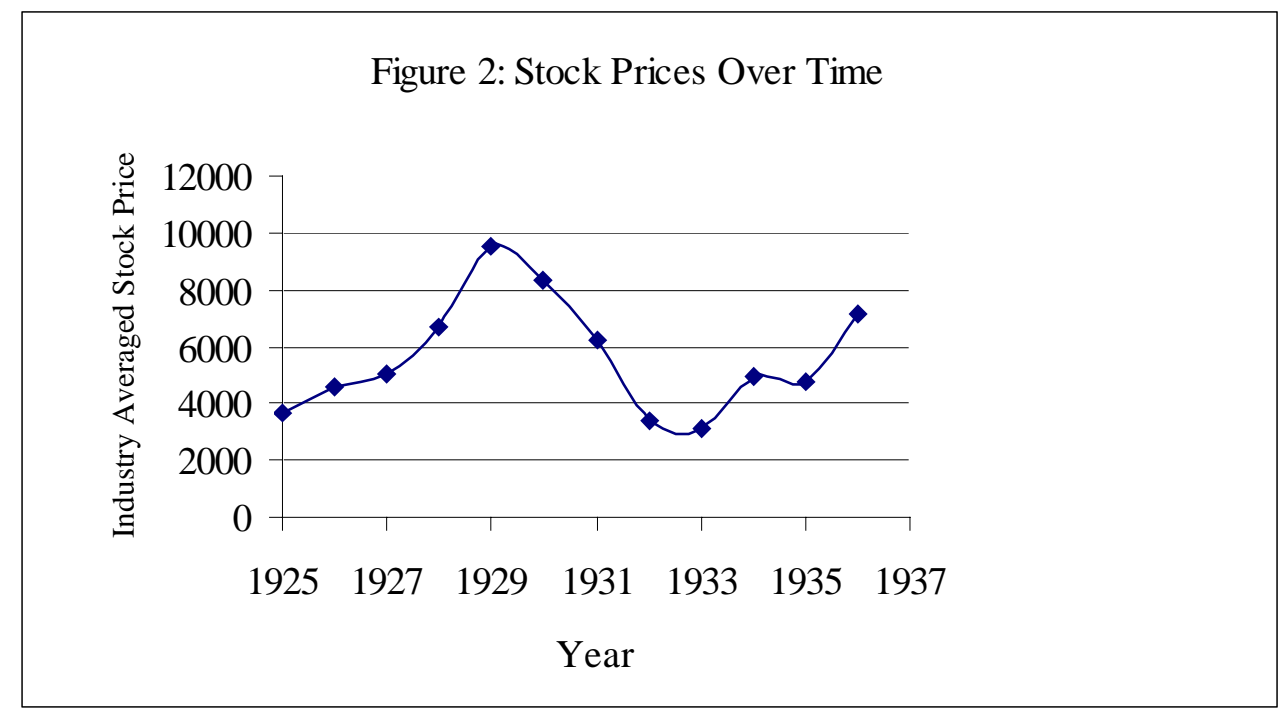

Notes: Industry averaged stock prices including cash dividends from Cowles (1938). 